\title{
Study on CMPO (Carbamoylphosphate) derivative functionalized ordered mesoporous silicates for selective removal of lanthanide
}

\author{
Bob Jin Kwon, Hyun Jung* and Jong Young $\mathrm{Kim}^{\dagger}$ \\ Korea Institute of Ceramic Engineering and Technology, Icheon Branch, Ichen 467-843, Korea \\ *Advanced Functional Nanohybrid Material Laboratory, Department of Chemistry, Dongguk University-Seoul Campus, Seoul \\ 100-715, Korea
}

(Received October 19, 2012)

(Revised November 21, 2012)

(Accepted November 30, 2012)

\begin{abstract}
Carbamoylphosphate (CMPO) [CMPO analogue; 2-(diphenylphosphoryl)-N-(3-(triethoxysilyl)propyl)acetamide]silane, as a functional self-assembled molecules, grafted mesoporous silicates were prepared by simple hydrolysis and condensation reaction. Pore sized tailored mesoporous silicates such as MCM-41, SBA-15, or amorphous silica nanoparticles were adopted as host materials. The surface area of ordered mesoporous silicates was ranged from $680 \mathrm{~m}^{2} / \mathrm{g}$ to $1310 \mathrm{~m}^{2} / \mathrm{g}$ with different pore diameters that estimated to be ca. 2.3 9.1 nm by BJH method. Among the OMMs host materials, SBA-15(II) has higher loading ratio $(\sim 35 \mathrm{wt} \%)$ of CMPO derivative than other OMMs. Accessibility to CMPO silane functional groups in the surface of mesoporous silicas was studied by lanthanide ions sorption experiments. All of the CMPO modified OMMs favors the smaller $\mathrm{Eu}(\mathrm{III})$ and $\mathrm{Nd}(\mathrm{III})$ cations than $\mathrm{La}$ (III) for relative larger ionic radius.
\end{abstract}

Key words Mesoporous silicate, CMPO derivative, Lanthanium sorption

\section{희토류 원소의 분리를 위한 표면 개질 된 메조 다공성 실리케이트의 개발에 관 한 연구}

권법진, 정현*, 김종영

한국 세라믹 기술원 이천 분원, 이천, 467-843

*동국대학교 화학과, 서울, 100-715

(2012년 10월 19일 접수)

(2012년 11월 21일 심사완료)

(2012년 11월 30일 게재확정)

요 약 자기 조립 분자 집합체 물질인 $\mathrm{CMPO}$ 로 표면개질 된 메조 다공성 실리케이트를 가수분해와 축합반응을 이용하 여 합성하였다. 손님 물질인 $\mathrm{CMPO}$ 는 2-(diphenylphosphoryl) acetic acid와 3-(triethoxysilyl) propan-1-amine의 아마이드 결합 반응을 이용하여 합성하였으며, MCM-41, SBA-15 그리고 실리카 나노입자와 같은 다양한 메조 다공성 실리케이트는 주인 물질로 채택하였다. 메조 다공성 실리케이트의 비표면적은 $680 \mathrm{~m}^{2} / \mathrm{g} 1310 \mathrm{~m}^{2} / \mathrm{g}$ 의 넓이로 측정되었으며 $\mathrm{BJH}$ 방법을 이용해 서 동공의 크기를 확인한 결과 2.3 9.1 nm 범위의 다양한 크기를 가지고 있었다. 메조 다공성 실리카 중에서는 SBA-15(II) 가 가장 높은 약 $35 \mathrm{wt} \%$ 의 $\mathrm{CMPO}$ 함유량을 나타내었다. 메조 다공성 실리케이트의 표면에 개질된 $\mathrm{CMPO}$ 실란 작용기와 란탄족 이온과의 접근성에 관한 연구 결과, $\mathrm{CMPO}$ 로 개질 된 모든 흡착제의 경우 상대적으로 이온 반경이 큰 $\mathrm{La}(\mathrm{III})$ 보다 는 크기가 작은 $\mathrm{Nd}(\mathrm{III})$ 와 $\mathrm{Eu}(\mathrm{III})$ 이온을 더 선호하였다.

\footnotetext{
Corresponding author

Tel: +82-31-645-1423

Fax: +82-31-645-1438

E-mail:jykim@kicet.re.kr
} 


\section{1. 서 론}

방사성 동위원소의 생산은 최종소비에 적합한 형태로 만들어지기 위해서 여러 단계를 필요로 하며, 일반적으 로 전 과정이 하나의 시설에서만 이루어지지 않고, 여러 다른 시설을 이용하여 생산되고 있다. 방사성동위원소 생산 시설들은 주로 원자로 가속기들 그리고 방사성 동 위원소를 생산하는데 이용되는 분리 시설들을 포함하고 있다. 이렇게 생산된 방사성동위원소들을 분리 하는데 있어 많은 연구가 지속되고 있으며 다양한 시도가 광범 위하게 이루어지고 있다. 현재 치료용으로 생산되는 방 사성 핵종은 란탄계열의 원소들 $\left({ }^{153} \mathrm{Sm},{ }^{166} \mathrm{Ho}\right.$ 그리고 ${ }^{177} \mathrm{Lu}$ 등)이 많이 이용되고 있다. 그러나 치료용 핵종 생 산에 있어 가장 중요한 점은 치료용 핵종의 최종제품 품 질을 보장하기 위해 무담체 상태로 생산되어야 하는데, 이런 측면에서 원자로에서 생성된 방사성 원소들의 분리 및 정제는 상당히 중요하다고 볼 수 있다.

방사성 중금속의 분리는 여러 가지 유기인 화합물들을 추출제로 이용한 용매 추출법을 주로 사용해왔다 $[1,2]$. 기존의 용매 추출법은 방사 화학적 관점에서는 대량의 방 사성 유기 폐기물이 발생하며 그 공정이 다단계로 구성되 어 있어 복잡하다는 단점을 지니고 있다. 이러한 용매 추 출법의 단점을 극복하기 위해서는 각 방사성 금속 이온에 대한 선택성이 보다 뛰어나고, 희토류금속에 대한 친화력 이 강한 새로운 추출제를 개발하여 할 필요성을 가지고 있다. 일반적으로, 희토류원소 분리 시 사용되는 분자는 phosphate기를 가진 알콕시 실란과 아민 반응기를 가진 알콕시 실란을 사용하며, 이를 $\mathrm{SiO}_{2}$ 나 고분자 레진 담체 에 피착시켜 충진제 형태로 사용하고 있다 $[1,3,4]$.

전통적으로 zeolite와 같은 다공성 물질들은 주로 흡착 제나 지지체 및 촉매담체로서 응용되고 있다[5-7]. 최근 10 년간 다양한 형태의 다공성 물질 중 메조 다공성물질에 대한 연구가 활발히 수행되고 있는데 IUPAC(International Union of Pure and Applied Chemistry) 분류에 따르면 메조다공성물질이란 $2 \sim 50 \mathrm{~nm}$ 크기의 동공을 가지는 물 질을 뜻하며 1991년 미국의 mobil사에서 $\mathrm{MCM}$ 계열을 발표한 이후 전기, 전자, 촉매, 담체, 바이오 분야 등 다 양한 분야에서 그 응용성 연구에 수행되고 있다. 이러한 $\mathrm{MCM}$ 계열은 그 결정구조에 따라 MCM- $41,48, \mathrm{SBA}-$ 15 등 다양한 형태를 갖으며 총체적으로 $\mathrm{OMM}($ Ordered Mesoporous Material)이라고 칭하기도 하는데, 이 $\mathrm{OMM}$ 은 그 비표면적이 $600 \mathrm{~m}^{2} / \mathrm{g}$ 이상으로 대단히 높고 또한 매우 규칙적이며 균일한 동공 크기를 가지고 있다[8]. 특히 $\mathrm{OMM}$ 을 이용한 폐수 중 중금속 흡착제거에 관한 선행 연구 결과를 보면 중금속 흡착 특성이 $\mathrm{OMM}$ 의 동 공 크기에 크게 의존함을 알 수 있는데 각 동공 크기의 변화에 따라 특성 원소에 대한 선택적 흡착 특성을 부여
할 수 있게 된다 $[8,9] . \mathrm{CMPO}$ 유도체의 $\mathrm{P}=\mathrm{O}$ 작용기와 $\mathrm{C}=\mathrm{O}$ 작용기 사이에 킬레이팅 할 수 있는 이온 반경이 란탄 이온들의 반경과 거의 유사하므로 다른 이온 종들 과 섞여 있을 때 선택적인 흡착 거동을 보일 것으로 기 대하였다. 따라서 본 연구에서는 동공 크기가 조절된 메 조 다공성 $\mathrm{OMM}$ 물질을 설계하고 그 표면에 선택적으 로 희토류원소를 흡착하는 특성을 지닌 $\mathrm{CMPO}$ 를 하이 브리드화시켜 유 - 무기 복합체를 형성하고 이를 이용하 여 핵분열 생성물 중 부생성물 인 희토류 원소를 효과적 으로 분리하고자 한다.

\section{2. 실험방법}

\section{1. $\mathrm{CMPO}$ 유도체의 합성}

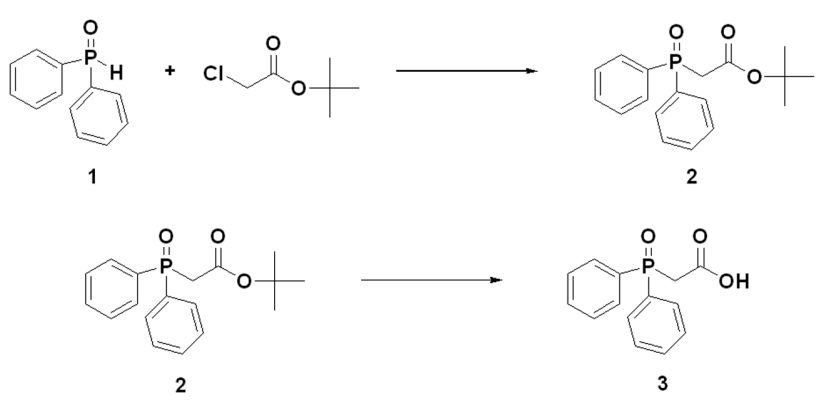

2.1.1. tert-butyl-2-(diphenylphosphoryl)acetate(2) 합성

Dimethyl sulfoxide $5 \mathrm{~m} l$ 에 $3 \mathrm{~g}(14.84 \mathrm{mmol})$ 의 1 을 녹 인 뒤 $54 \%$ 포타슘 하이드록사이드 수용액 $1 \mathrm{ml}$ 를 천천 히 첨가한 후 5 분간 교반한다. 투명한 색에서 노란색으 로 용액의 색변화가 관찰되면, 터-부틸-클로로아세테이트 $2.68 \mathrm{~g}(17.81 \mathrm{mmol})$ 를 천천히 첨가하고, 3시간 동안 실 온에서 교반한다. 박층 크로마토그래피로 반응을 확인한 후 $10 \mathrm{~m} l$ 의 메틸렌클로라이드로 3 회 추출한다. 분별한 유기 용액을 포화 소금 용액으로 씻어준 후 무수 황산나 트륨으로 건조한 후 여과하여, 용액을 감압 증류하여 농 축시킨다. 컬럼 크로마토그래피를 통해 분리하여, 24 시간 동안 용매를 제거하였으며, $3.52 \mathrm{~g}(11.13 \mathrm{mmol})$ 의 tert-butyl-2-(diphenylphosphoryl)acetate(2)를 흰색 분말 로 얻었다.

\subsubsection{2-(diphenylphosphoryl)acetic $\operatorname{acid}(\mathbf{3})$ 의 합성}

$3.52 \mathrm{~g}(11.13 \mathrm{mmol})$ 의 2 를 메틸렌클로라이드 $3 \mathrm{~m} /$ 에 녹인 뒤 Trifluoroacetic acid(TFA) $5 \mathrm{ml}$ 을 첨가한 후, $60^{\circ} \mathrm{C}$ 에서 교반한다. 박층 크로마토그래피로 반응완결을 확인한 후, 용매를 감압 증류하여 제거하고, 잔류물에 포 화 소듐바이카보네이트 수용액 $10 \mathrm{ml}$ 을 첨가한다. $5 \mathrm{ml}$ 의 메렌클로라이드로 추출한 후 수층에 $1 \mathrm{M}$ 의 염산을 
산성조건이 될 때까지 첨가한 뒤, $10 \mathrm{ml}$ 의 메틸렌클로라 이드로 3회 추출한다. 분별한 유기용액을 감압 증류하여 용매를 제거하여, $1.627 \mathrm{~g}(6.25 \mathrm{mmol})$ 의 2-(diphenylphos phoryl)acetic $\operatorname{acid}(3)$ 를 노란 액체를 얻었다.

\section{2. 동공의 크기가 조절된 메조 다공성 실리카 주형의 합성}

동공의 크기가 다양한 주형 물질을 합성하기 위하여, 계면활성제나 공중합체 고분자를 사용하였으며, 같은 공 중합체를 사용한 SBA-15(I)와 SBA-15(II)는 각 각 수열 합성의 온도를 다르게 하여 서로 다른 동공을 갖는 메조 다공성 실리케이트를 합성하였다.

\subsubsection{MCM-41}

$\mathrm{CTAB}$ 를 3 차 증류수에 용해 시키고 소듐실리케이트 용액을 첨가하여 $\mathrm{pH}$ 가 8 이 되도록 조절한 다음 24 시간 동안 상온에서 숙성시킨 후 $550^{\circ} \mathrm{C}$ 에서 하소(calcination) 한다.

\subsubsection{SBA-15-(I)}

공중합체 $\mathrm{EO}_{20} \mathrm{PO}_{70} \mathrm{EO}_{20}$ 를 3 차 증류수에 5시간 용해시 킨 후 $1 \mathrm{M} \mathrm{HCl}$ 과 $\mathrm{TEOS}$ 를 첨가한 후 24시간 동안 숙성 시킨다. 그 후 좀 더 균일한 동공크기가 형성될 수 있도 록 $100^{\circ} \mathrm{C}$ 에서 수열합성방법을 사용하여 열처리를 한 후 마지막으로 $500^{\circ} \mathrm{C}$ 에서 하소하여 고분자 주형를 제거한다.

\subsubsection{SBA-15-(II)}

공중합체 $\mathrm{EO}_{20} \mathrm{PO}_{70} \mathrm{EO}_{20}$ 를 증류수에 5시간 분산시킨 후 $1 \mathrm{M} \mathrm{HCl}$ 과 $\mathrm{TEOS}$ 를 첨가한 후 24 시간 동안 $60^{\circ} \mathrm{C}$ 에 서 aging시킨 후 $120^{\circ} \mathrm{C}$ 에서 수열합성 방법으로 열처리 를 한다. 그 후 $500^{\circ} \mathrm{C}$ 에서 하소한다.

\subsection{4. 실리카 나노입자}

TEOS : water : ethanol : $\mathrm{NH}_{4} \mathrm{OH}=0.5 \mathrm{~mol}: 1 \mathrm{~mol}$ : $17 \mathrm{~mol}: 1.5 \mathrm{~mol}$ 비율로 섞고 6 시간 동안 교반 시킨 후 $90^{\circ} \mathrm{C}$ 에서 건조시켜서 얻는다.

\section{3. $\mathrm{CMPO}$ 유도체와 메조다공성 물질과의 하이브리드 반응}

메조다공성 실리카 주형 물질을 진공 건조기에서 $70^{\circ} \mathrm{C}$ 에서 충분히 건조시킨 후에 톨루엔 용매 $100 \mathrm{ml}$ 안에 질소 분위기에서 충분히 분산시킨다. 주형물질인 실리카 입자가 충분히 분산된 플라스크 안에 $\mathrm{CMPO}$ 유도체를 천천히 주입하고 $80^{\circ} \mathrm{C}$ 에서 24 시간 충분히 교반시킨 후 ethanol로 원심 분리 과정을 거친 후에 공기 중에서 drying시킨다. 동공의 크기와 비표면적에 따른 란탄족 이 온의 흡착거동을 $\mathrm{La}(\mathrm{III}), \mathrm{Nd}(\mathrm{III}), \mathrm{Eu}(\mathrm{III})$ 그리고 $\mathrm{Er}(\mathrm{III})$ 이온을 이용하여 측정하였다. $2.0 \mathrm{M}$ 의 질산 용액에 $0.1 \mathrm{M}$ 의 sodium nitrate 용액을 첨가하여 $\mathrm{pH}$ 가 4.0 인 버퍼용액을 만든 후, 용액 대 용질의 비가 200이 되도록 고체 흡착제를 용액에 첨가하여 1 시간 동안 시킨다. 각 각의 용액들은 란탄족 이온의 농도가 $4.0 \mathrm{ppm}$ 이 되도록 하고, 흡착제가 이온을 접합 한 후에 $2,4,6,8,10,15$, 20,30 분 시간 별로 용액을 취하여 농도를 측정하였다.

\section{3. 실험결과 및 고찰}

\section{$\mathrm{CMPO}$ 유도체의 합성 여부는 ${ }^{1} \mathrm{H}-\mathrm{NMR}(200 \mathrm{MHz}$,}

Table 1

${ }^{1} \mathrm{H}-\mathrm{NMR}\left(200 \mathrm{MHz}, \mathrm{CDCl}_{3}\right.$ ) data of tert-butyl-2-(diphenylphosphoryl)acetate and 2-(diphenylphosphoryl)acetic acid compounds

\begin{tabular}{ll}
\hline CMPO derivative & $\begin{array}{l}{ }^{1} \mathrm{H}-\mathrm{NMR}(200 \mathrm{MHz}, \\
\left.\mathrm{CDCl}_{3}\right)\end{array}$ \\
\hline tert-butyl-2-(diphenylphosphoryl)acetate $\delta 7.78(\mathrm{~m}, 4 \mathrm{H}), 7.52(\mathrm{~m}$, \\
& $6 \mathrm{H}), 3.56(\mathrm{~d}, 2 \mathrm{H}), 1.23(\mathrm{~s}$, \\
& $9 \mathrm{H})$ \\
& $\delta 7.78(\mathrm{~m}, 4 \mathrm{H}), 7.52(\mathrm{~m}$, \\
2-(diphenylphosphoryl)acetic acid & $6 \mathrm{H}), 3.56(\mathrm{~d}, 2 \mathrm{H}), 1.23(\mathrm{~s}$, \\
& $9 \mathrm{H})$ \\
\hline
\end{tabular}

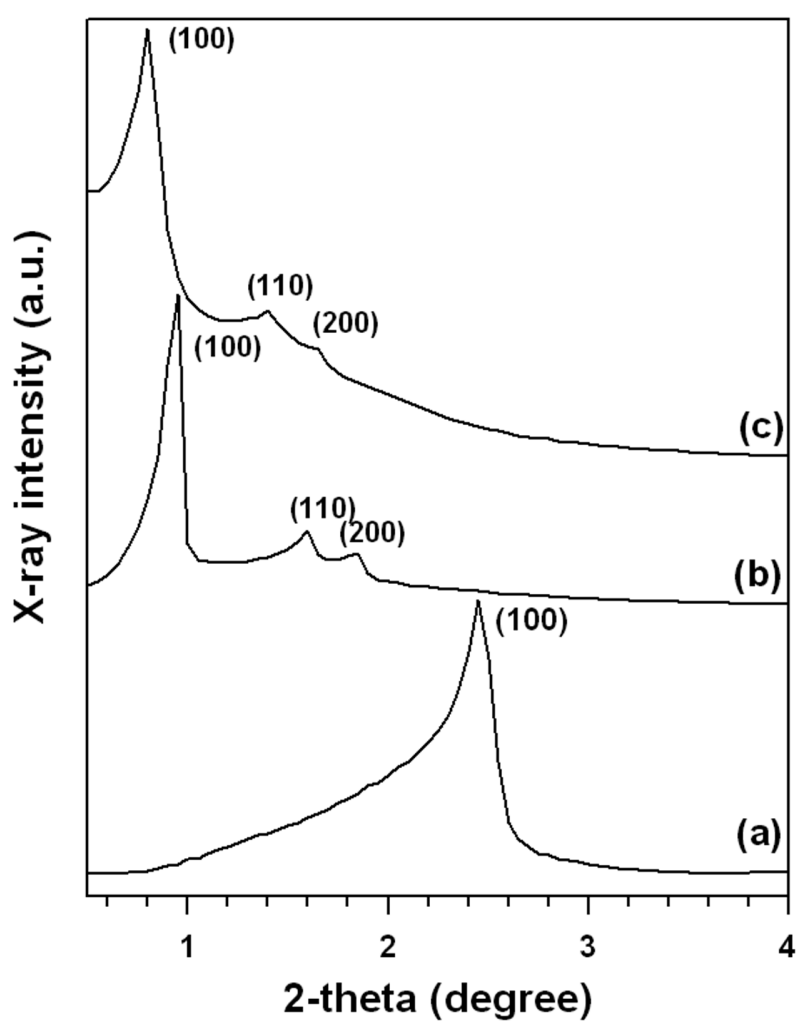

Fig. 1. SAXS patterns for host mesoporous materials [(a) MCM-41, (b) SBA-15(I) and (c) SBA-15(II), respectively]. 
$\mathrm{CDCl}_{3}$ )를 이용하여 측정하였으며, 그 결과는 Table 1 과 같이 성공적으로 합성 되었음을 확인하였다. Fig. 1의 small angle X-ray scattering(SAXS) 분석결과 메조 다 공성 실리카는 균일한 크기의 동공을 가지고 육각형 모 양으로 규칙적으로 배열되어 있다. 동공은 원통모양으로 이루어져 있으며 $100,110,200$ 주소의 피크(peak)로 확 인 해본 결과, 매우 규칙적인 동공을 메조 다공성 실리 카가 성공적으로 합성되었음을 알 수 있었다. SAXS의 100 회절 패턴을 d 값을 이용하여 얻어진 물질의 cell parameter인 $a$ 값을 구할 수 있었다[10].

동공의 크기 및 모양과 같은, 동공에 대한 보다 정확 한 정보를 얻기 위해 $\mathrm{TEM}$ 측정 방법을 통하여 확인하 였다. Fig. 2 의 이미지에 의하면 $\mathrm{MCM}-41$ 의 경우 동공 의 크기는 $2.5 \mathrm{~nm}$ 이며 동공의 벽두께는 $3.0 \mathrm{~nm}$ 로 나타 났다. SBA-15(I)과 SBA-15(II)의 경우에는 동공의 크기 가 각각 $5.5 \mathrm{~nm}, 8.5 \mathrm{~nm}$ 인 균일한 동공 크기의 실리카 주형이 합성되었음을 확인 하였다. 또한, 비교 군으로 합 성한 실리카 나노입자의 경우 그 평균 입자크기가 83.4 $\mathrm{nm}$ 이고 구형의 모양을 가지고 있었다. 입자의 크기 분
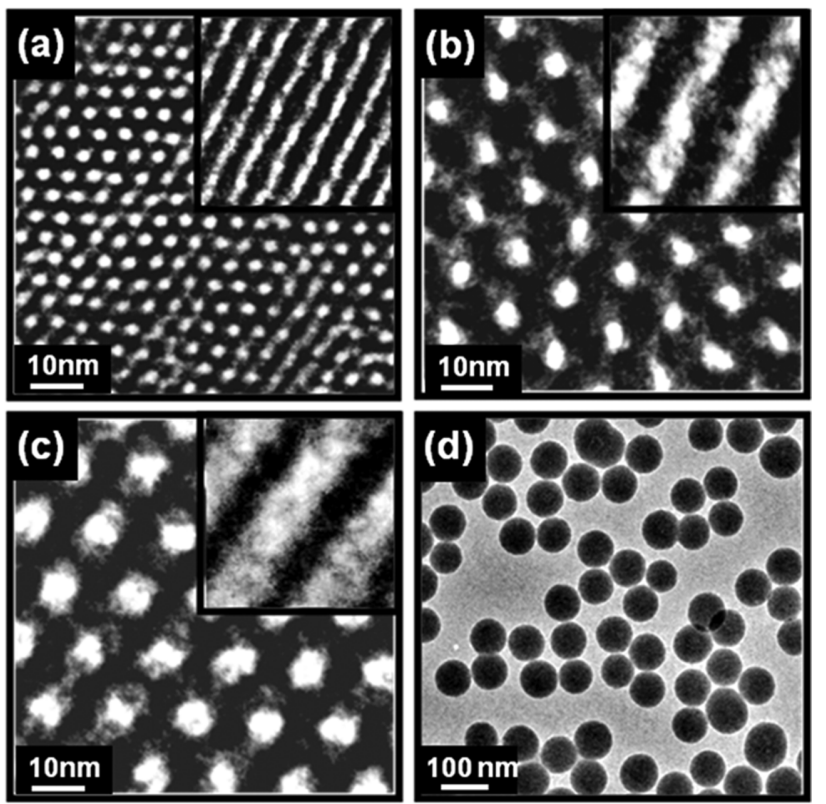

Fig. 2. HR-TEM cross sectional images of host materials [(a) MCM-41, (b) SBA-15(I), (c) SBA-15(II) and (d) Silica nanoparticle, respectively. The inset images in (a), (b) and (c) show unidirectional channels of the open mesoporous structure].

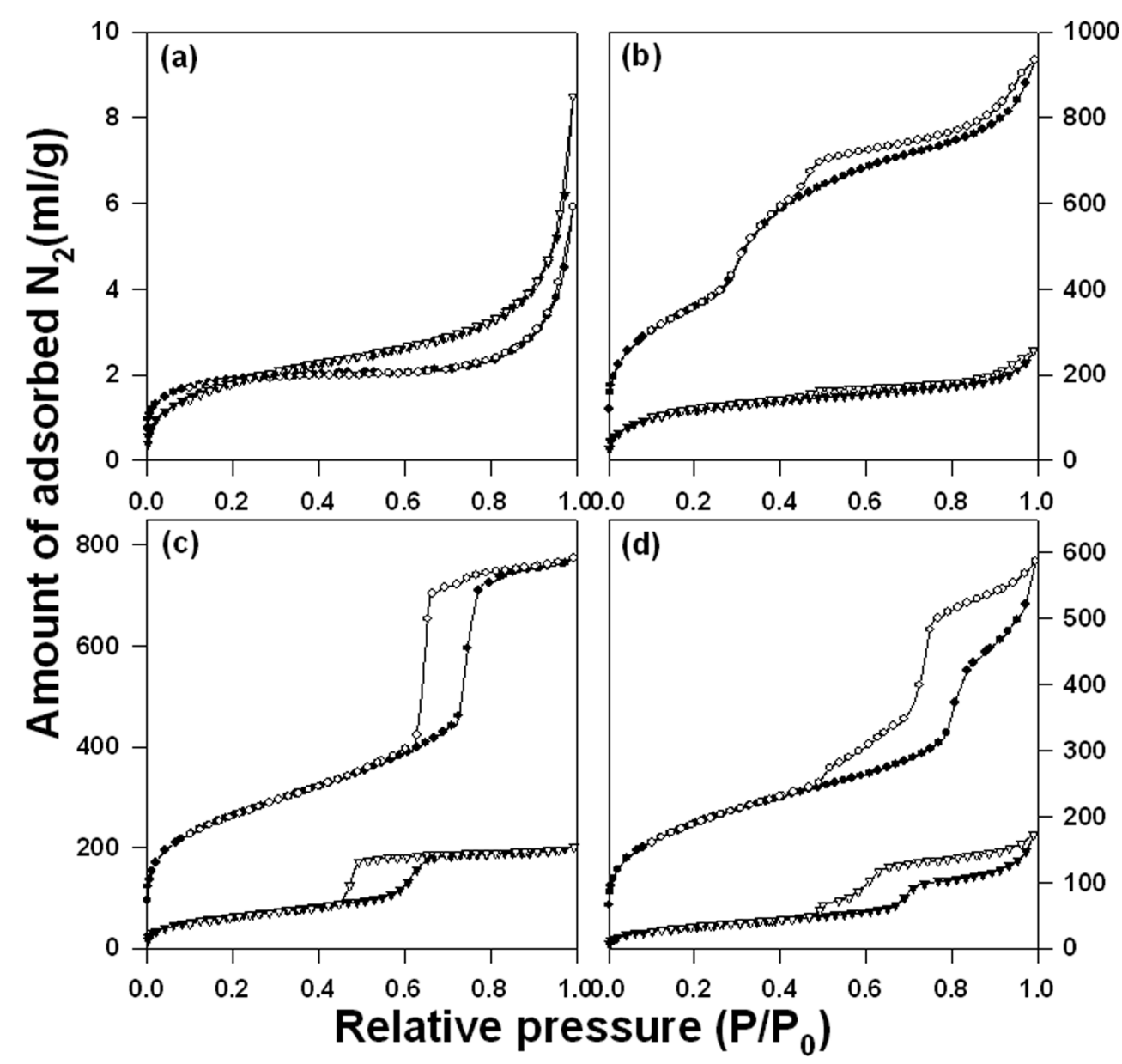

Fig. 3. The nitrogen adsorption (empty symbols)-desorption (filled symbols) isotherms curves of before (circle)/after (triangle down) and grafting CMPO derivative on host materials [(a) Silica nanoparticle respectively (b) MCM-41 (c) SBA-15 (I) (d) SBA-15 (II)]. 
포 분석을 통해 크기의 표준편차가 $0.5 \mathrm{~nm}$ 인 매우 균일 한 나노입자가 합성되었음을 알 수 있었다.

합성된 OMMs host 물질의 다공특성을 평가하기 위 하여 $\mathrm{N}_{2}$ 흡탈착 실험을 수행하였다. $\mathrm{N}_{2}$ 흡탈착 실험을 통하여 얻어진 다공체에 형성된 동공구조 및 비표면적에 대한 자세한 정보를 얻을 수 있었다. Fig. 3에 나타나 듯이 MCM-41의 경우 BDDT(Brunauer, Deming, Deming and Teller) 등온 곡선 분류방식에 의해 Type IV형으로 분류할 수 있으며 $\mathrm{H3}$ 형의 이격곡선 모양을 나타냈다. Type IV는 메조다공성 물질의 전형적인 질소 흡탈착 곡 선의 형태이며 이격곡선의 존재는 주로 메조크기의 동공 을 갖는 물질에서 나타나는 특이한 현상이다. 얻어진 질 소 흡탈착 곡선을 이용하여 $\mathrm{MCM}-41$ 다공체의 비표면 적과 동공크기 분포도를 얻을 수 있다. MCM-41 메조다 공성 실리카는 $\mathrm{BET}$ specific surface 표면적이 1310 $\mathrm{m}^{2} / \mathrm{g}$ 으로 계산되었으며 동공의 크기는 $2.3 \mathrm{~nm}$ 에서 최대 분포를 나타내었다. SBA-15(I)와 SBA-15(II)의 질소 흡
탈착 등온곡선의 경우 Type IV의 메조다공성 특성과 $\mathrm{H} 2$ 형의 이격곡선을 보였다. 특히, $\mathrm{H} 2$ 형의 이격곡선 모 양은 그 동공이 열린(open) 형태임을 의미하며 동공의 입구와 동공 내부의 반경이 같은 실린더 모양 혹은 채널 형태의 다공성 물질에서 관찰된다. 이는 앞서 언급한 $\mathrm{TEM}$ 결과와 일치하는 데이타로써 성공적으로 규칙적인 메조 다공성 실리케이트가 합성되었음을 뒷받침한다고 할 수 있었다. SBA-15(I)과 SBA- $15(\mathrm{II})$ 는 계산에 의해 $\mathrm{BET}$ 비표면적 값이 각각 $950 \mathrm{~m}^{2} / \mathrm{g}, 680 \mathrm{~m}^{2} / \mathrm{g}$ 으로 나타 났으며 동공의 크기 분포도에 의해 $7.6 \mathrm{~nm}, 9.1 \mathrm{~nm}$ 에서 최대값을 나타내었다. SBA-15(II)의 경우 SBA-15(I)에 비해 aging 시간 및 수열 합성 시 반응온도를 더 높게 함으로써 template로 작용하는 blockcopolymer의 분자 간의 운동에너지를 증가시켜 결과적으로 보다 큰 동공 크기의 메조 다공성물질이 합성되었다고 설명할 수 있다. 마지막으로 비교 군으로 합성한 실리카 나노입자의 경우 대단히 낮은 비표면적 $\left(7.0 \mathrm{~m}^{2} / \mathrm{g}\right)$ 을 보였으며 질소 흡탈착

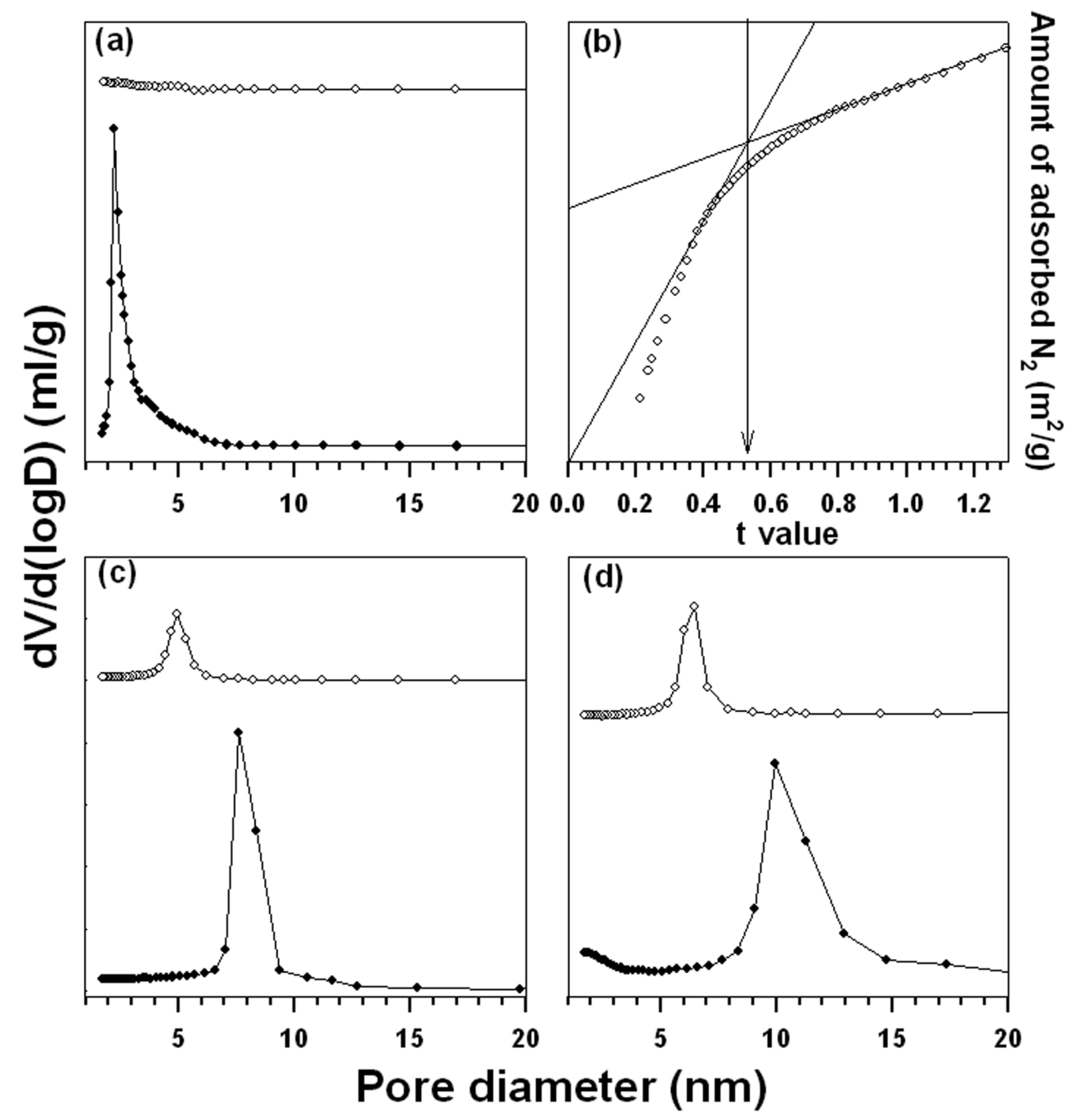

Fig. 4. The pore size distribution curves of (a) MCM-41, (c) SBA-15(I) and (d) SBA-15(II) (before and after grafting reaction) and the $t$-plot for MCM-41 grafted with CMPO derivative (b). 
등온곡선 역시 type II로 nonporous한 물질의 거동과 유 사한 형태를 나타내었다. 또한, 등온선을 이용한 $\mathrm{BJH}$ 동공 분석결과 나노입자 사이의 불규칙적인 응집에 의해 상대적으로 대단히 넓은 범위에서 걸친 동공 분포도를 나타내었다. 이는 실리카 나노입자 물질은 불규칙적인 동공 크기를 가지고 있음으로 설명될 수 있다.

다양한 동공의 크기와 비표면적을 가지고 있는 메조다 공성 실리카 주형에 $\mathrm{CMPO}$ 유도체를 접합시킨 후 복합 체의 다공 특성의 변화를 확인하기 위하여 $\mathrm{N}_{2}$ 흡탈착 실험을 측정하였다. 동공의 벽 안으로 $\mathrm{CMPO}$ 유도체가 접합되면서 주형과는 다른 동공의 크기와 비표면적의 변 화로써 실제로 $\mathrm{CMPO}$ 유도체가 접합되었는 지를 확인 하고 동공의 크기에 따른 접합률의 영향을 알 수 있다. Fig. 4 에 동공 분포 곡선을 확인한 결과, $\mathrm{MCM}-41$ 의 경 우 주형의 동공의 크기가 $2.3 \mathrm{~nm}$ 이고 $\mathrm{CMPO}$ 유도체의 길이가 대략 $1.4 \mathrm{~nm}$ 되므로 동공 안에 단일층 형태로 접합할 수 없다. 따라서 grafting에 의해 생성된 동공은 마이크로 다공 특성을 보일 것으로 예상할 수 있었으며
그 결과 메조다공성 물질 분석 방법인 $\mathrm{BJH}$ 동공 분석으 로 특성을 분석할 수 없었다. 따라서 마이크로 다공체의 동공 분석법인 t-plot을 이용하여 동공크기를 계산할 수 있었다. 계산결과 약 $1.1 \mathrm{~nm}$ 의 크기임을 알 수 있었고 이는 $\mathrm{CMPO}$ 유도체의 길이에 비해 $\mathrm{MCM}-41$ 의 동공크 기가 작아 동공의 벽 안쪽을 완전히 단일층으로 개질하 지 못한 것으로 보인다. SBA-15(I)의 경우에는 접합 전 후 모두 type IV의 특징을 갖고 $\mathrm{H} 1$ type의 히스테리시 스 루프를 보아 원통형 동공(cylinderical pore)의 모양을 유지하는 것으로 보아 동공 안에 균일하게 $\mathrm{CMPO}$ 유도 체가 접합되었음을 확인할 수 있었다[11]. 동공의 크기 가 $7.6 \mathrm{~nm}$ 에서 $4.9 \mathrm{~nm}$ 로 변화한 것은 $\mathrm{CMPO}$ 유도체의 길이가 $1.4 \mathrm{~nm}$ 인 것을 감안하면 동공의 안쪽을 따라서 균일하게 접합하고 있다는 것을 알 수 있다. 또한 열분 석과 원소분석 결과에 나온 $\mathrm{CMPO}$ 유도체의 접합률이 가장 크게 나타나고 있는 것으로 보아 동공의 크기가 $7.6 \mathrm{~nm}$ 가 가장 적당했다. SBA-15(II)의 경우에는 동공의 크기는 가장 컸지만 상대적으로 작은 비표면적 때문에
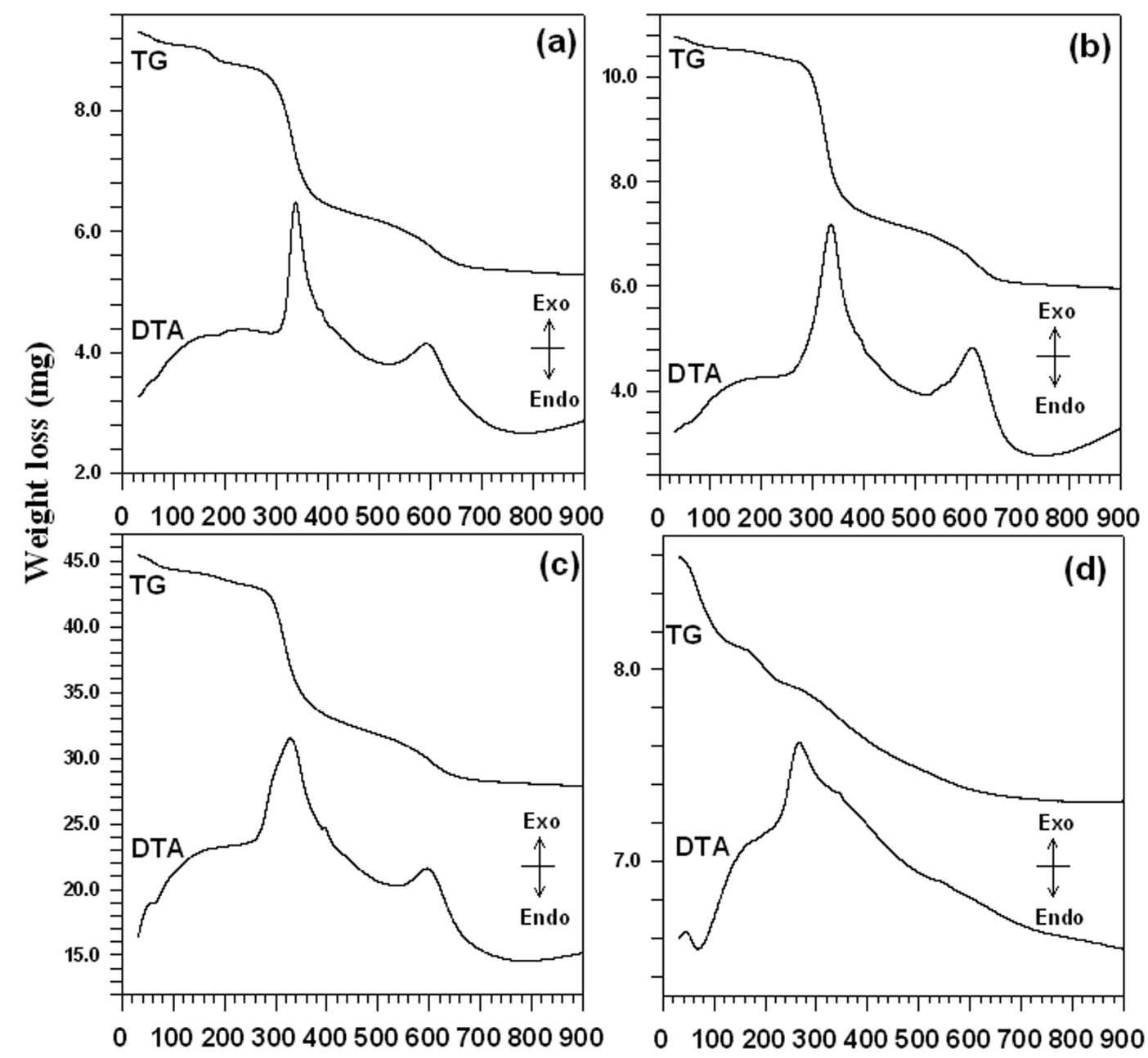

Fig. 5. TG and DTA curves of CMPO analogue modified host materials [(a) MCM-41, (b) SBA-15(I), (c) SBA-15(II) and (d) Silica nanoparticle, respectively]. 


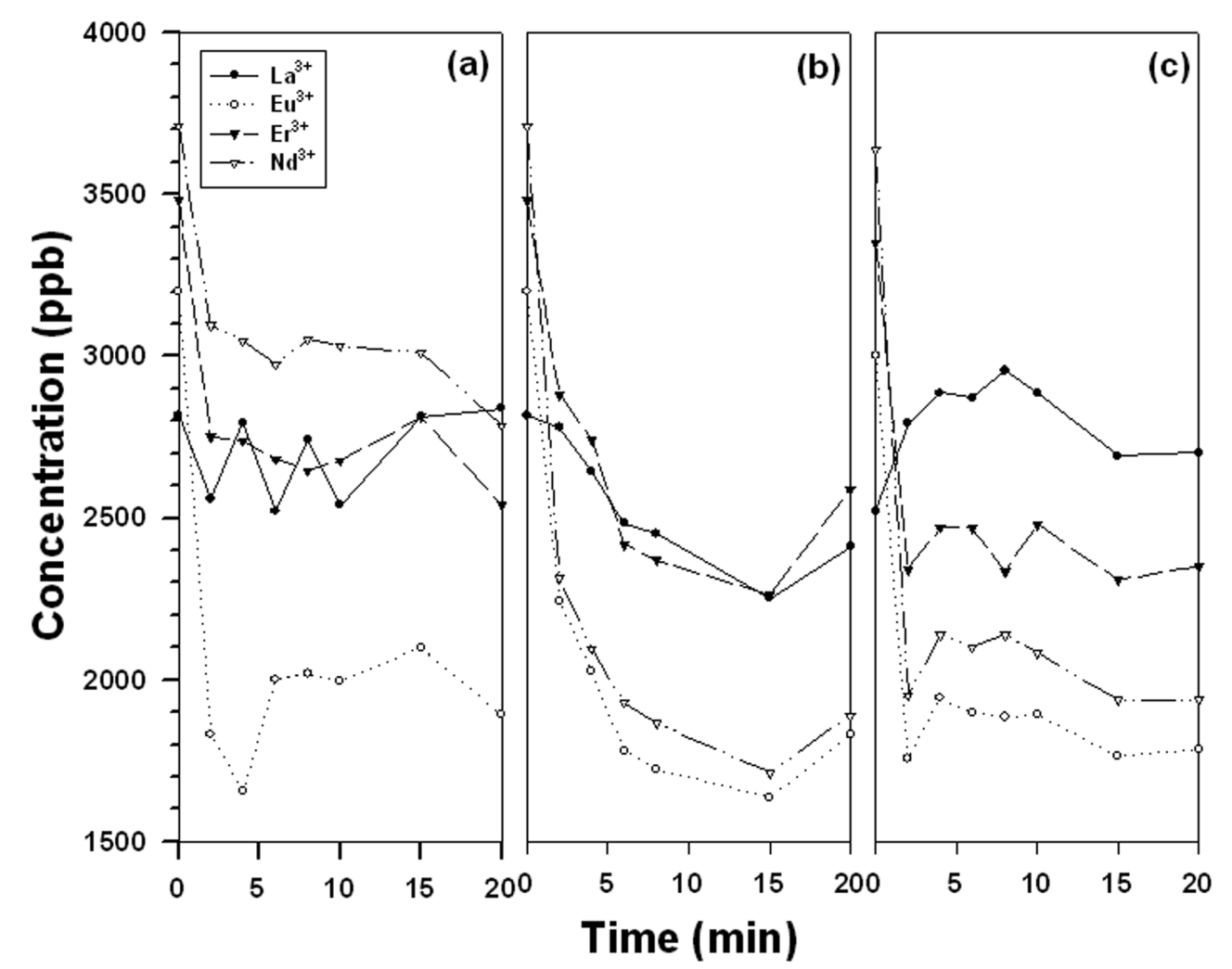

Fig. 6. Kinetics of lanthanide sorption on CMPO modified ordered mesoporous silicates [(a) MCM-41, (b) SBA-15(I) and (c) SBA-15(II)].

$\mathrm{MCM}-41$ 보다 접합률이 낮게 나타났다. 동공의 크기의 변화를 살펴보면 $9.1 \mathrm{~nm}$ 에서 $6.0 \mathrm{~nm}$ 로 줄어드는 것으로 보아 SBA-15(I)의 경우와 같이 동공의 안쪽으로 균일하 게 접합되었음을 확인할 수 있었다. 실리카 나노입자의 경우에는 불규칙적인 동공의 크기로 뚜렷한 동공의 크기 의 변화는 확인되지 않았으며 다른 메조다공성 물질에 비해서 확연히 작은 비표면적 $(6.8 \%)$ 과 $\mathrm{CMPO}$ 함유량 $(6.3 \%)$ 을 갖고 있음을 확인하였다.

$\mathrm{CMPO}$ 유도체가 표면 처리된 메조다공성 물질의 열적 거동을 알아보기 위해 열분석를 수행하였다. 이를 통해 $\mathrm{CMPO}$-다공체 복합체의 대략적인 $\mathrm{CMPO}$ 의 함량을 계 산할 수 있고, hybrid 물질의 열적 안정성에 대해 이해 할 수 있었다. Fig. 5에 곡선은 전체적인 열분석 결과는 크게 세 부분으로 나눌 수 있었다. RT에서 150도 사이 에 흡열과정을 동반하는 무게감소는 다공체 동공 표면에 흡착되었던 물과 용매의 증발에서 기인하는 것이며 200 도-500도 사이의 큰 발열과정을 수반하는 무게 감소는 유기물과 $\mathrm{CMPO}$ 분자의 열분화 과정에 의한 현상으로 설명될 수 있다. 마지막으로 500도 이상의 구간에서의 발열과정을 수반하는 무게 감소는 다공체 표면의 잔존하 는 하이드록시기 $(\mathrm{OH})$ 의 dehydroxylation 과정과 $\mathrm{CMPO}$ 유도체의 $\mathrm{P}$ 부분이 산화되면서 일어나는 무게 감소이다. 열분석에 의해서 $\mathrm{CMPO}$ 유도체가 얼마나 메조다공성
물질에 함량 되었는지 결정할 수 있는데 SBA-15(I)의 경우 함유량이 $31 \%$ 로 가장 높게 나왔고 실리카 나노입 자의 경우는 $9 \%$ 로 가장 낮게 나타났다. 실리카 나노입 자의 동공은 입자 사이의 공간에서 나타나기 때문에 다 른 메조다공성 실리카보다 동공의 규칙성이 떨어지고 그 에 따라서 $\mathrm{CMPO}$ 유도체의 접합율도 낮게 나타나게 된 것으로 판단된다.

Fig. 6의 란탄족 이온의 흡착 실험 결과, 흡착 속도는 2분 안에 대부분이 일어날 정도로 매우 빠른 속도로 이루어졌으며, 이온 반경이 상대적으로 작은 $\mathrm{Eu}(\mathrm{III})$ 와 $\mathrm{Nd}(\mathrm{III})$ 이 흡착이 더 잘 일어났다. 이는 육각형 킬레이트 (chelating) 될 때 $\mathrm{CMPO}$ 유도체가 좀더 작은 이온을 선 호하는 데에서 이유를 찾을 수 있다. 그리고 표면 개질 된 메조 다공성 실리카 주형의 경우 흡착 이온의 양이 전체적으로 적은 이유는 $\mathrm{CMPO}$ 유도체가 가지고 있는 페닐(phenyl)기가 동공의 안 쪽을 소수성 분위기로 만들 어서 이온이 녹아있는 물이 동공 안쪽으로 침투하기 힘 들기 때문이다.

\section{4. 결 론}

본 연구에서는 희토류 원소를 선택적으로 흡착할 수 
있는 표면 개질된 메조 다공성 실리카를 합성해 그 구조 적 특성과 란탄족 이온과의 흡착 선호도 평가에 주안을 두었다. 동공의 크기와 모양이 다른 4가지의 실리카 주 형을 성공적으로 합성하였으며, 동공 안에 균일한 두께 의 CMPO 유도체를 grafting시켰다. 희토류 원소의 흡착 실험 결과, 이온 반경이 상대적으로 작은 $\mathrm{Eu}(\mathrm{III})$ 와 $\mathrm{Nd}(\mathrm{III})$ 이 흡착제와의 인력이 더 강하게 나타났다. 이는 육각형 킬레이트(chelating) 될 때 좀더 작은 이온을 선 호하는 것이 원인으로 생각된다.

\section{참 고 문 헌}

[ 1 ] N. Leventis, I.A. Elder, D.R. Rolison, M.L. Anderson and C.I. Merzbacher, "Durable modification of silica aerogel monoliths with fluorescent 2,7-diazapyrenium moieties. Sensing oxygen near the speed of open-air diffusion", Chem. Mater. 11 (1999) 2837.

[2 ] Ch. Siva Kesava Raju and M.S. Subramanian, "A novel solid phase extraction method for separation of actinides and lanthanides from high acidic streams", Separation and Purification Technology 55 (2007) 16.

[3] R. Pathak and G.N. Rao, "Synthesis and metal sorption studies of $p$-tert-butylcalix[8]arene chemically bound to polymeric support”, Anal. Chem. Acta 335 (1996) 283.

[4] D. Prabhakaran and M.S. Subramanian, "Selective extraction of U(VI), Th(IV), and La(III) from acidic matrix solutions and environmental samples using chemically modified Amberlite XAD-16 resin”, Anal. Bional. Chem. 379 (2004) 519.

[5] A. Corma, "From microporous to mesoporous molecular sieve materials and their use in catalysis", Chem. Rev. 97 (1997) 2373.

[ 6 ] D.E.W. Vanughan, "Pillared clays - a historical perspective", Catal. Today 2 (1988) 187.

[ 7 ] S.M. Herman, P.L. Zelia, L.O. Rodrigo, L.V. Wander, O. Cintia and J.M. Lucas, "Surface functionalization of porous glass networks: Effects on bovine serum albumin and porcine insulin immobilization", Biomacromolecules 1 (2000) 789.

[8] K. Kim and S. Kang, "Characterization of artificial aggregates fabricated with direct sintering method", Journal of the Korean Crystal and Crystal Technology 1 (2011) 34.

[9] J.H. Sin, K.B. Park and T.H. Kim, "The adsorption efficiency of ceramic filter media prepared with the steelmaking slag for the removal of VOCs", Journal of the Korean Crystal and Crystal Technology 3 (2010) 153.

[10] H.P. Lin and C.Y. Mou, "Control of morphology in synthesizing mesoporous silica", Science 273 (1996) 765.

[11] D. Zhao, J. Sun, Q. Li and G.D. Stucky, "Morphological control of highly ordered mesoporous silica SBA15", Chem. Mater. 9 (2000) 275.

[12] A. Katiyar, S. Yadav, P.G. Smirniotis and N.G. Pinto, "Synthesis of ordered large pore SBA-15 spherical particles for adsorption of biomolecules", J. Chromatogr. A 1122 (2006) 13.

[13] T. Allen, in: Particle Size Measurement, Champman and Hall, London (1997). 